\title{
PEER TUTORING STRATEGY TO TEACH READING COMPREHENSION
}

\author{
Kholifuddin Roma, Y. Gatot Sutapa Y., Sudarsono \\ Tanjungpura University \\ Email: Khlifuddin@gmail.com
}

\begin{abstract}
This study was a quasi-experimental study. It was to find out the use of peer tutoring strategy and its significant effect to teach reading comprehension. The population of this research was the whole year-8 students of SMP NEGERI 2 Pontianak. Cluster random sampling was used to determine the sample. The samples were students of year- $8 \mathrm{H}$ as the experimental group and year- $8 \mathrm{D}$ as the control group. Measurement technique was employed in this research. The tool of collecting data was reading test and further analyzed by using SPSS software. The research result showed that peer tutoring strategy was effective to teach reading comprehension and Ho rejected since $t$ value $>\mathrm{t}_{\text {table }}$ (5.081 $>2.0032$ ). The result of the effect size calculation yielded a strong effect (1.237). In brief, it can be concluded that peer tutoring strategy had the strong effect in teaching reading comprehension of narrative text. It is suggested to be applied in teaching reading comprehension
\end{abstract}

Keywords: Peer Tutoring Strategy, Reading Comprehension, Narrative Text

\section{INTRODUCTION}

Reading comprehension is an interactive process that goes on between the reader and the text, resulting from a comprehension. It means there is a communication that arises between the reader and the text during the reading process. Therefore, students should be able to comprehend and understand texts. In the school context, teachers are encouraged to ask students to read various kinds of texts before they start the teaching process. This aims to increase the students' literacy. Literacy is perceived as the capability of reading and writing in certain language skill. Literacy has some advantages. Students can be more accustomed to read and be more familiar with absorbing information around them. The literacy program is developed by Ministry of Education and Culture. Currently, several Indonesian schools have been applying literacy program to their students.
The students should be able to understand various kinds of texts based on school-based curriculum for English lesson. They are narrative, recount, procedure, descriptive, news item, report, analytical exposition, hortatory expo-sition, spoof, explanation, discussion and review text. These texts have their own language features, social functions, and generic structures. One of the texts that should be learned by the year- 8 students of Junior High School is narrative text.

The narrative text is a type of text in the form of imaginary stories, real stories, or fairy tales. The narrative text tells a story that has a series of chronologically connected events. The purpose of narrative text is to entertain the readers. In addition, the students learning the narrative text can know and understand the settings where and when the narrative story occurs. The students can understand the differences between one place and another. The 
students also should be able to distinguish places and times between one story and another. The students can recognize their respective characters and should be able to distinguish which characters are inappropriate to imitate, and which characters are exemplary

However, the researcher has observed and found that most of the year- 8 students of SMP NEGERI 2 Pontianak in the academic year of 2018/2019 encountered several problems in comprehending reading text. Those problems could be caused the students and the learning environment that posed difficulties in reading comprehension. This happened because the students were focused to understand certain reading text individually. The students had to do this without having the opportunity to discuss their ideas with their friends. In addition, the problems also could come from the students themselves because they considered English as a difficult lesson.

Regarding the reading compre-hension problems found, the researcher considered that peer tutoring was an appropriate strategy to increase the students' reading comprehension. Bouchard (2005, p.105) claims that peer tutoring strategy is an effective strategy for reading comprehension because the tutors could help the group member that had difficulties to comprehend the text. Peer tutoring strategy could encourage the students to be active in learning process and learn by using small teaching assisting them to understand the text better. The teaching atmospheres are comfortable when interacting with a peer who is the same level and age.

Peer tutoring strategy has been proven to increase the students' reading comprehension, provide better learning atmosphere, and make the students engage in the class actively (O'Shea \& O'Sheam, 2010, p.806). In addition, peer tutoring strategy could eliminate awkwardness among students. With peers as the tutors, there was no sense of reluctance, low self-esteem, shyness and afraid of asking questions (Kapil \& Malini, 2017, p.7792).
Therefore, the researcher believed it could increase the students' reading comprehension.

The use of peer tutoring strategy in teaching reading comprehension has been applied in several researches (e.g. Alzahrani \& Leko, 2018; Blanch, Duran, Flores, \& Valdebenito, 2012; Zambrano \& Gisbert 2015). They claim that peer tutoring strategy was very effective to teach the students' reading comprehension ability. Those researches were conducted abroad in which the English language was their first and second language. Thus, the current research is very essential because it deals with the area where there is just a little info offered and was conducted research to students with the English language as their foreign language.

Those researchers chose the tutors from students with higher level (cross-age) while this researcher chose the tutors from their classmate (the same-age). The cross-age peer tutoring strategy is a teaching process pairing the senior students to the junior student in small teaching or workgroup (Kapil \& Malini, 2017, p.7793). The same-age peer tutoring strategy is a teaching process pairing the students with other students with the same age and level in small teaching or workgroup (Kapil \& Malini, 2017, p.7793).

The researcher also found that Prihatno (2014) conducted research on improving students' reading com-prehension through peer tutoring strategy. The research finding showed that peer tutoring strategy could make the students more motivated in the learning process. That research was focused on improving the quality of teaching process while this research was focused on increasing the students' reading com-prehension. Therefore, the researcher was encouraged to find out the use of peer tutoring strategy and its significant effect to teach reading comprehension of the narrative text to Year-8 Students of SMP NEGERI 2 Pontianak. Furthermore, it believed could solve the students' the reading comprehension problems. 


\section{METHOD}

This research employs experimental research. It involves making a change in the value of one variable called the independent variable and observing the effect of the change on another variable called the dependent variable where the essential feature of the experimental research is that investigators deliberately control and manipulate the conditions determining the events in which they are interested (Cohen, Manion, \& Morrison, 2007, p.272).

The researcher used intact groups in conducting quasi-experimental research and could use cluster random assig-nments to groups. This is because the experiment cannot create an artificial group for experiments (Creswell, 2012, p.309). The quasiexperimental research is similar to randomized experimental but it has different because it is not randomly assigned to treatment groups and the quasi-experimental is not giving full control (Ary, Jacobs, Sorensen, \& Razavieh, 2010, p.316).

The researcher tried to find out the effectiveness of independent variable to dependent variable, meaning whether the independent variable could change and affect the dependent variable by comparing the students' achievement and score of post test from both experimental and control group. However, the control group did not receive the treatment by teaching narrative text through peer tutoring strategy because the researcher taught the control group by using common strategy used. Lodico, Spaulding, and Voegtle (2011, p.234) define the control group as a separate group that receives no treatment or has a different treatment than the experimental group but it is equal to the experimental group in every other way.

Research population is very essential components in conducting research because the researcher should find out his interest in the group characteristic. Creswell (2012, p.381) defines the population as a group of individuals having a certain characteristic that distinguishes them from other groups. The research population of this research is Year-8 Students SMP NEGERI 2 Pontianak

The researcher used cluster sampling. Lodico, et al., (2011, p.216) define cluster sampling as selecting and obtaining the lists of groups rather than lists of individuals. Furthermore, the researcher used the lottery to take the sample from the population. The researcher wrote the class name in the small paper and folded each small paper. Then, the researcher put the paper in a box and shook the paper well after that the researcher opened the box, took one paper as the experimental group, and took one paper again as the control group.

\section{RESULT AND DISCUSSION}

\section{Result}

The researcher collected the data from the experimental and control group by giving them a test. Each class consisted of twenty-nine students and the researcher took them by using cluster random sampling after testing the homogeneity of the population. In addition, the researcher only focused on teaching reading comprehension with five indicators, identifying the main idea, finding supporting detail, determining reference, drawing the inference, and understanding the meaning of the vocabulary.

The researcher calculated the students' individual score firstly. The researcher found out that the nineteen students in the experimental group from the pre test got 20 until 60 and others students got 64 until 76 . From the post test, one student only got 52 , seventeen students got 64 until 80, other students got 84 until 92. In addition, the researcher also calculated the students of the control group from the pre test in which twenty-one students got 28 until 60 and other students got 64 until 72 . From the post test, ten students got 32 until 60 , and nineteen students got 64 until 80 . 
In this research, the researcher tried to find out the effectiveness of peer tutoring strategy to teach reading comprehension of narrative text to Year-8 Students SMP NEGERI 2 Pontianak. The researcher used two classes, the students of Year- $8 \mathrm{H}$ as the experimental group and Year-8 $\mathrm{D}$ as the control group. Therefore, the researcher used SPSS of Independent Sample T-Test to analyse the data. Analyzing the data through independent sample t-test could show the homogeneity between the two groups. The result can be seen on this table.

\section{Table 1. Independent Samples Test}

\begin{tabular}{|c|c|c|}
\hline \multirow{2}{*}{$\begin{array}{c}\text { Levene's Test } \\
\text { for Equality of } \\
\text { Variances }\end{array}$} & $\mathrm{F}$ & .406 \\
\hline & Sig & .527 \\
\hline \multicolumn{3}{|c|}{$\begin{array}{l}\text { Equal variances assumed } \\
\text { t-test for Equality of Means }\end{array}$} \\
\hline \multicolumn{2}{|l|}{$\mathrm{T}$} & 5.081 \\
\hline \multicolumn{2}{|l|}{ Df } & 56 \\
\hline \multicolumn{2}{|l|}{ Sig.(2-tailed) } & .000 \\
\hline \multicolumn{2}{|l|}{ Mean Difference } & 13.379 \\
\hline \multicolumn{2}{|c|}{ Std. Error Difference } & 2.633 \\
\hline \multirow{2}{*}{\multicolumn{2}{|c|}{$\begin{array}{l}95 \% \text { Confidence Interval of } \\
\text { the Difference }\end{array}$}} & $\begin{array}{ll}\text { Lower } & 8.105 \\
\end{array}$ \\
\hline & & Upper \\
\hline \multicolumn{3}{|c|}{$\begin{array}{l}\text { Equal variances not assumed } \\
\text { t-test for Equality of Means }\end{array}$} \\
\hline \multicolumn{2}{|l|}{$\mathrm{T}$} & 5.081 \\
\hline \multicolumn{2}{|l|}{ Df } & 54.543 \\
\hline \multicolumn{2}{|l|}{ Sig.(2-tailed) } & .000 \\
\hline \multicolumn{2}{|l|}{ Mean Difference } & 13.379 \\
\hline \multicolumn{2}{|c|}{ Std. Error Difference } & 2.633 \\
\hline \multirow{2}{*}{\multicolumn{2}{|c|}{$\begin{array}{l}95 \% \text { Confidence Interval of } \\
\text { the Difference }\end{array}$}} & Lower 8.101 \\
\hline & & Upper \\
\hline
\end{tabular}

To find out the homogeneity, the researcher made hypotheses. Null hypothesis (Ho) was both experimental and control group had the same variances and alternative hypothesis (Ha) both experimental and control group did not have the same variance. In addition, if significant value $>0.05$ meant Ho accepted while if significant value $<0.05$ meant Ho rejected. Based on the table mentioned above, the significant value of variances was 0.527 , meaning it was bigger than $0.05(0.527>0.05)$. In short, Ho accepted or both the experimental and control group had the same variances.

The researcher used the column of equal variances assumed to analyze the effectiveness of peer tutoring strategy in teaching reading comprehension of narrative text because both groups had the same variance. There were two ways to find out the effectiveness, $t$ value and significant value. Peer tutoring strategy was effective if $t$ value was bigger than table or $t$ value $>t_{\text {table. }}$. Based on the table above, $t$ value was 5.081 and $\mathrm{t}_{\text {table }}$ was 2.0032 , meaning $t$ value was bigger than $t_{\text {table }}(5.081>2.0032)$ so that $\mathrm{Ha}$ accepted or peer tutoring strategy was effective.

Seen from significant value, if significant value $<0.05$ meant $\mathrm{Ha}$ accepted while if significant value $>0.05$ meant $\mathrm{Ha}$ rejected. Based on the table mentioned above, the significant value of variances was 0.000 , meaning it was lower than $0.05(0.000<0.05)$ so that Ha accepted. From both sides, it could be concluded that peer tutoring strategy was effective in teaching reading comp-rehension of the narrative text to year-8 students of SMP NEGERI 2 Pontianak in the academic year of 2018/2019.

Furthermore, the researcher also analyzed the effect size of peer tutoring strategy to teach the students' reading comprehension. From the calculation, the value of the effect size was 1.237. It belonged to strong effect based on criteria. In short, peer tutoring strategy had the strong effect in teaching reading comprehension of the narrative text to year- 8 students of SMP NEGERI 2 Pontianak in the academic year of 2018/2019

\section{Discussion}

Reading comprehension is a process to obtain information and knowledge from 
authors. The students reading an English text bring many positive benefits because it could influence and improve their under-standing, structure, and other skills. In this research, the researcher tried to increase and improve to year-8 students' reading comprehension of SMP NEGERI 2 Pontianak through peer tutoring strategy in the experimental group and using question answer relationship strategy in the control group, in which it was a strategy usually applied by the real English teacher.

When the researcher applied both strategies, the researcher could conclude that peer tutoring strategy could make the students more active and efficient in teaching reading comprehension to the students. It emphasized the students to learn actively in small teaching so that the students could be active in discussing the narrative text and brave to ask each other if they had difficulties to comprehend the text during the teaching process. Actually, question answer rela-tionship strategy demanded the students to ask each other or to be active. Unfortunately, many students could not be active because question answer relationship strategy only asked the students to learn individually while peer tutoring strategy could make the students to learn in a group well.

Peer tutoring is an effective strategy for reading comprehension because the tutors could help the group member that had difficulties to comprehend the text. The students can involve with the learning process directly so that they become active students in receiving information and get responses and improvements quickly (Rahmasari, 2017, p.256). When the researcher taught reading comprehension through peer tutoring strategy the students liked the strategy because the students got an opportunity to discuss English text among them. Learning with friends could make the students become more enthusiastic in learning activities than if they study alone. Several students not understanding the material did not hesitate to ask the teachers since the students studying in the group could ask and discuss lessons with their friends freely.

Learning in the group really made the students fun rather learning individually. Alfares (2017, p.254) claims that learning in a group or group work could improve the students' motivation and inspiration to learn, and knowledge. It creates more opportunities and more freedom to practice English. Learning in a group gives advantage for both students and teachers because students participating well in colla-borative learning gain better grades and more satisfied with their achievement (Burke, 2011, p.87). In addition, the researcher chose one of the group members to a tutor at his/her group. The tutor was chosen because the researcher considered that tutor at that group understood the best than other members.

This strategy gave the tutor an opportunity to practice and enhance his understanding by guiding others. $\mathrm{He}$ also explained the materials taught by the researcher and gave an opportunity to his members to ask, discuss and share the material. He told his own strategy to understand the material. The students usually are passive in the teaching process they could be active in this teaching process because they did not feel shy to ask and convey an idea. In short, the peer tutoring is a very appropriate strategy to improve learning activities and enhance students' confidence level and they become self motivated (Ali, Anwer, \& Abbas, 2015, p.65).

The tutor felt proud of their roles and taught his members from his experiences. This could help to strengthen what has been learned. The students also developed better abilities to organize, organize, and understand what learned and followed the learning strategy given. His explanation used familiar languages. In this case, the students got motivated to share their understanding and discuss the material well. This strategy was great because the students got many opportunities to take part and involve the learning process in asking 
questions, discussing and using the new knowledge actively. In addition, the researcher made the students involve in the learning process actively. The researcher guided and controlled the students' discussion by checking what they were doing and discussing at their group.

When the students had problems being studied, they could find the solution easier to solve the problems because it could involve the minds of two or many people. Tiwari (2014, p.12) claims that the small group discussions or learning with peers could help students understand the materials taught while developing communication skills and increasing the awareness of their classmates as a learning resource. In addition, after the researcher divided the students into several groups they looked very enthusiastic in the learning process with their classmates because they could share a similar discourse and enable better understanding.

Previous researches have shown that that teaching reading comprehension through peer tutoring strategy was very effective to teach and increase the students' reading comprehension ability (Alzahrani \& Leko, 2018; Blanch, Duran, Flores, \& Valdebenito 2012; and Zambrano \& Gisbert 2015). Currently, this research result also showed that peer tutoring strategy had the strong effect to teach the students' reading compre-hension of narrative text. In addition, peer tutoring strategy made the students more quickly understand what was taught by their friends as the tutor, compared to what was taught by the teacher. The tutor recognizes his friends' ways to learn and understand the material.

Based on the result of data analysis and findings, the researcher concluded that the peer tutoring strategy could give more opportunity to the students to take a part and engage in the learning process, make the students more active and get motivated to learn reading compre-hension. In short, peer tutoring strategy had the strong effect to teach reading comprehension of the narrative text to year- 8 students of SMP NEGERI 2 Pontianak in the academic year of 2018/2019.

\section{CONCLUSION AND SUGGESTION Conclusion}

Based the research finding and discussion, it can be concluded that peer tutoring strategy had the strong effect to teach reading comprehension to the students because it could make the students get more active in a teaching and learning process. It has been proven that peer tutoring strategy was definitely more effective than question answer relationship strategy in teaching reading comprehension of narrative text. It could help the students with a low achievement to increase their motivation and spirit in understanding the narrative text because they learned it in a group with a tutor having high achievement that guided, helped, and explained the material well.

Peer tutoring strategy made passive students to become active students because the students learning in the small group could interact with a peer who was the same level and closed friend so that the students felt very happy and comfortable. In addition, peer tutoring strategy could sharpen the tutor's understanding and comprehending a certain material because the tutor tried to transfer his knowledge to the members and make them a better understanding. The students also got many opportunities to discuss and share the materials that were not understood and the tutor tried to explain again and again until the students understood the material.

\section{Suggestions}

From the conclusion above, there are some suggestions that are proposed by the researcher. The teachers have to be careful in picking a teaching strategy because a good teaching strategy will encourage students' learning achie-vement and motivation in the teaching and learning process. Peer tutoring 
strategy can be used as a reference for the English teacher to teach reading comprehension because it has been proven that it could increase the students' reading comprehension and improve the teaching quality because it really demands the students to be active in the learning and teaching process. In addition, peer tutoring stra-tegy also can be applied to teach other skills, listening, speaking, and writing because it is a very suitable teaching strategy to make active in the learning and teaching process.

Students should often read the English text. It could help and increase students' better English skills, such as listening, speaking, and writing skill. Actually, students have their very own individual learning strategy in understanding an English text. This can be ad-derssed by peer tutoring strategy because it involves the students as a small group where they could learn to solve their own problems. In addition, peer tutoring strategy should be practiced by students to develop their reading comprehension effectively.

This research is expected to be useful to further researchers who are interested in conducting similar research. Peer tutoring strategy has confirmed to be an efficient and effective strategy in teaching reading comprehension. That is why the further study on peer tutoring strategy could be applied to various population and characteristics, whether the same finding could be attained or otherwise.

This research also has a limitation. The researcher cannot control the students perfectly because from five times treatments a few students do not join and attend school fully during conducting research. The further researcher should overcome and anticipate it by making sure that the students should come when the treatment is being done or he just focuses on the students who can attend and join the treatments fully.

\section{REFERENCES}

Alfares, N. (2017). Benefits and difficulties of learning in group work in EFL classes in saudi arabia. English Language Teaching, 10(7), 247-256.

Ali, N., Anwer, M., \& Abbas, J. (2015). Impact of peer tutoring on learning of students. Journal for Studies in Management and Planning, 1(2).

Alzahrani, T., \& Leko, M. (2018). The effects of peer tutoring on the reading comprehension performance of secondary students with disabilities: A systematic. Reading \& Writing Quarterly. 34, 1-17, DOI: 10.1080/10573569.2017.1302372

Ary. D., Jacobs, L. C., Sorensen.C., \& Razavieh, A. (2010). Introduction to research in education. Canada: Wadshworth

Blanch, S., Duran, D., Flores, M., \& Valdebenito, V. (2012). The effects of a peer tutoring programme to improve the reading comprehension competence involving primary students at school and their families at home. Procedia - Social and Behavioral Sciences, 46, 1684 - 168

Bouchard, M. (2005). Comprehension strategies for English language learners. New York: Scholistic Inc

Burke, A. (2011). Group work: How to use groups effectively. Journal of Effective Teaching, 11(2), 87-95.

Cohen, L., Manion, L., \& Morrison, K. (2007). Research methods in education (6 ${ }^{\text {th }} \mathrm{Ed}$.). New York: Routledge

Creswell, J. W. (2012). Educational research: Planning, conducting and evaluating quantitative and qualitative research $\left(4^{\text {th }}\right.$ Ed.). New York: TexTech International

Kapil, Y., \& Malini, S. J. (2017) Peer tutoring an instructional strategy: A systematic approach. Scholarly Research Journal for Humanity Science \& English Language. 6/27 7792-7798 
Lodico, M., Spaulding, D., \& Voegtle, K. (2010). Method in education research. San Fransisco: Jossey-Bass

O'Shea, L. J., \& O'Shea, D. J. (2010). Peertutoring. In P. Peterson, E. Baker \& B. McGaw (Eds.), International Encyclopedia of Education (Third Edition) (pp. 802-807). Oxford: Elsevier. doi.org/10.1016/B978-0-08-0448947.01139-8

Prihatno, Y. I. (2014). Improving grade $x$ students' reading comprehension by using peer tutoring at MAN III Yogyakarta
(Thesis' Bacholar), Yogyakarta State Universit, Yogyakarta.

Rahmasari, B. S. (2017). Peer Tutoring: An effective technique to teach reading comprehension. $\mathrm{KnE} \quad$ Social Sciences, 1(3), 245-258.

Tiwari, M. (2014). Peer tutoring: A step forward towards inclusion. Educationia Confab, 3(14), 10-17

Zambrano, V. V., \& Gisbert, D. D. (2015). The coordinating role of the teacher in a peer tutoring programme. Procedia-Social and Behavioral Sciences, 191, 2300-2306. 